\title{
CYCLING TRAINING AND FUNCTIONAL ELECTRICAL STIMULATION FOR POST-STROKE PATIENTS
}

\author{
TREINAMENTO DE CICLISMO EESTIMULAÇÃO ELÉTRICA FUNCIONAL PARA PACIENTES PÓS ACIDENTE \\ VASCULAR CEREBRAL
}

\author{
ENTRENAMIENTO DE CICLISMO Y ESTIMULACIÓN ELÉCTRICA FUNCIONAL PARA PACIENTES \\ POSTATAQUEVASCULARCEREBAL
}

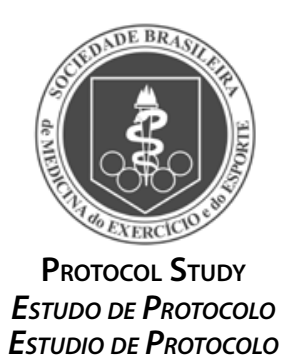

Ardalan Shariat ${ }^{1}$

(Exercise Therapist)

Noureddin Nakhostin Ansari ${ }^{1,2}$

(Physiotherapist)

Brandon S. Shaw

(Physiologist)

Ramin Kordi ${ }^{1}$

(Sports Medicine Specialist)

Mehdi Kargarfard ${ }^{4}$

(Physiologist)

Ina Shaw ${ }^{3}$

(Physiologist)

\section{Tehran University of Medical Sciences, Neuroscience Institute, Sports Medicine Research Center, Tehran, Iran. \\ 2. Tehran University of Medical Sciences, School of Rehabilitation Department of Physiotherapy, \\ Tehran, Iran. \\ 3. University of Zululand, \\ Department of Human Movement \\ Science, Kwazulu-Natal, Republic of South Africa. \\ 4. University of Isfahan, Faculty of Sport Sciences, Department of Exercise Physiology, Isfahan, Iran.}

\section{Correspondence:}

Tehran University of Medical Sciences, Department of Physiotherapy, School of Rehabilitation, Tehran, Iran. Enghelab Ave, Pich-e-shemiran, 11489. nakhostin@sina.tums.ac.ir

\begin{abstract}
Introducion: Stroke is one of the leading causes of morbidity and mortality in adults worldwide. The prevalence of stroke in developing countries such as South Africa and Iran is growing, especially in an increasingly younger population. In Iran, the annual stroke incidence ranges from 23 to 103 per 100,000 inhabitants, with the rate being higher in those aged $15-45$ years. Problematically, almost $50 \%$ of stroke patients face difficulties in performing activities of daily living, hence the importance of functional rehabilitation. These factors necessitate cost-effective solutions in developing countries, where there is insufficient research focused on practical solutions for treatment/rehabilitation. Objective: We hypothesize that while progressive cycling training would activate cortical regions and that cycling speed feedback could lead to additional cortical activations and resultant improvements in cycling performance, combined cycling training and functional electrical stimulation would result in superior improvements in cycling performance, aerobic capacity, and functional performance in post-stroke patients. Conclusions: Ultimately, we expect this hypothesis to provide a useful framework for facilitating combined cycling and functional electrical stimulation rehabilitation research in post-stroke patient populations. Level of Evidence V; Expert opinion.
\end{abstract}

Keywords: Aerobic exercise; Stroke; Neurorehabilitation.

\section{RESUMO}

Introdução: Acidente vascular Cerebral é uma das principais causas de morbidade e mortalidade em adultos ao redor do mundo. A prevalência de AVC em países em desenvolvimento, como África do Sul elrã, tem aumentado principalmente na população cada vez mais jovem. No Irã, a incidência anual de AVC varia de 23 a 103 em cada 100000 habitantes, com aumento da taxa entre 15-45 anos. Problematicamente, quase 50\% dos pacientes que sofreram AVC tem dificuldade de praticar atividades cotidianas, por isso a importância da reabilitação funcional. Esses fatores exigem a necessidade de soluções econômicas nos países em desenvolvimento, onde há pesquisas insuficientes que focam em soluções práticas para o tratamento/reabilitação. Objetivo: nossa hipótese é que o treinamento ciclístico progressivo pode ativar regiões corticais e a resposta da velocidade do ciclismo levaria a ativação corticais adicionais e melhorias resultantes no desempenho do ciclismo, treinamento combinado de ciclismo e estimulação elétrica funcional resultariam em melhorias superiores no desempenho do ciclismo, na capacidade aeróbica e no desempenho funcional em pacientes pós-AVC. Conclusão: Por fim, nós esperamos que essa hipótese providencie uma estrutura útil para facilitar a pesquisa em treinamento combinado de ciclismo e reabilitação em estimulação elétrica funcional em pacientes pós-AVC. Nível de Evidência V; Opinião do especialista.

Descritores: Exercício; Acidente vascular cerebral; Reabilitação neurológica.

\section{RESUMEN}

Introducción: El accidente cerebro-vascular es una de las principales causas de morbilidad y mortalidad en adultos en todo el mundo. La prevalencia de accidente cerebro-vascular en países en desarrollo, como Sudáfrica e Irán, está en aumento, especialmente en una población cada vez más joven. En Irán, la incidencia anual de ataque varía de 23 a 103 por 100000 habitantes, y la tasa es más alta en personas de 15 a 45 años. El problema radica en que casi el 50\% de los pacientes que sufrieron un accidente cerebro-vascular tienen dificultad para realizar actividades de la vida diaria. De ahí la importancia de la rehabilitación funcional. Estos factores requieren la necesidad de soluciones rentables en los países en desarrollo, donde no hay suficiente investigación que se centre en soluciones prácticas para el tratamiento/rehabilitación. Objetivos: Nuestra hipótesis es que, mientras el entrenamiento de ciclismo progresivo activaría las regiones corticales y que la retroalimentación de la velocidad de ciclismo podría conducir a activaciones corticales adicionales y mejoras resultantes en el rendimiento del ciclismo, el entrenamiento combinado de ciclismo y estimulación eléctrica funcional daría como resultado 
mejoras superiores en rendimiento de ciclismo, capacidad aeróbica y rendimiento funcional en pacientes postataque. Conclusiones: En última instancia, esperamos que esta hipótesis proporcione un marco útil para facilitar el ciclo combinado y la investigación de rehabilitación de estimulación eléctrica funcional en poblaciones de pacientes post-ataque. Nivel de Evidencia V; Opinión del especialista.

Descriptores: Ejercicio Aeróbico, Accidente Cerebrovascular, Neuro-rehabilitación.

\section{INTRODUCTION}

Stroke is a non-communicable disease of increasing importance since it was the second most common cause of mortality in 1990 and ranked third concerning mortality in developed countries in 1990.' Stroke is also a significant cause of long-term disability and has potentially vast socioeconomic and emotional outcomes for communities and countries.

Stroke survivors are often at least partially dependent on other individuals and/or special equipment in performing activities of daily living (ADLs). ${ }^{2}$ This is because both their static and dynamic balance is usually heavily affected, and this increases the incidence of falls. ${ }^{3}$ In addition, lack of postural control has the greatest impact on a patients' gait and independent performance of ADLs, and such disability arises from limitations in activities and reduced participation in daily life tasks. ${ }^{4}$ With hemiplegia contributing significantly to an inability to perform meaningful activities and participate fully in life following stroke, improving motor outcomes after stroke is essential and an optimal and rapid therapeutic intervention is required. To improve outcomes after stroke, intervention focuses on improving not only the impairment level, but addressing activity limitations, such as walking and moving objects, and participation restrictions. ${ }^{6}$

\section{Role of cycling in post-stroke rehabilitation}

Previous studies have revealed that aerobic training (AT) improves aerobic capacity by an average of $2.27 \mathrm{~mL} . \mathrm{kg}^{-1} \cdot \mathrm{min}^{-17}$. Generally, post-stroke rehabilitative cycling is executed to increase aerobic capacity via continuous or interval training with a heart rate of $50 \%$ to $80 \%$ of maximum. ${ }^{7.8}$ Previous studies that have utilized cycling for the rehabilitation of post-stoke patients in different genders and ages, have generally utilized a flat duration of exercise training of not more than 30 minutes following three months of training. 9,10

In addition to an increased aerobic capacity, other benefits such as gait endurance, gait speed, and quality of life have been observed following post-stroke rehabilitative cycling. 11,12 These results are important in that walking restoration is known as the major aim of post-stroke lower-limb rehabilitation, and the speed of gait considered as a consistent deficit severity sign. ${ }^{13}$ In addition, trunk control is considered to be a significant requirement to control more compound limb activities, ${ }^{14}$ and as such, it is necessary to identify an available treatment which can improve trunk control in the early treatment phase. Considering this context, an excellent candidate seems to be cycling training. ${ }^{15}$

These benefits are due to the capability of the cycling motion, which can activate somatosensory receptors and create rising inputs to the central nervous system. ${ }^{16}$ Research in both stroke patients and healthy subjects have shown that proprioceptive inflow from movements of upper-limb can increase activation in the sensory and sensorimotor cortex (SMC), additional motor area (SMA), secondary sensory cortex and premotor cortex (PMC), with resulting enhancement in performance of motor. ${ }^{17}$

\section{Role of electrical stimulation in post-stroke rehabilitation}

Electrical stimulation, in the form of Functional Electrical Stimulation (FES), especially when combined with other established modes of rehabilitation, such as cycling, has the potential to improve motor outcomes post-stroke and as such, potentially lead to increased activity performance and participation. ${ }^{18}$ This is because, while FES has limited benefits of its own, ${ }^{19} \mathrm{FES}$ can be utilized to enhance the effect of cycling in post-stroke rehabilitation.

Problematically, while limited studies have investigated the effects of FES on cycling, there is a clear variance among previous studies about the combined cycling and FES exercise design. In this regard, it is important to note that there is a need to propose a combined cycling and FES exercise protocol than can easily be performed in an in-patient or out-patient setting. ${ }^{13}$ To ensure success, the exercise protocol should not only replicate those successful cycling studies, but also provide novel and effective prescriptions for combining FES. ${ }^{14}$

\section{CONCLUSIONS}

To this end, this paper suggests a three times weekly progressive pattern of passive cycling with FES for five weeks, with an initial duration of 10 minutes (including two minutes warm-up and two minutes cool-down of passive cycling) in first week for neuromuscular adaptation. This initial pattern should be followed for three sessions in first week to allow for neuromuscular adaptations to take place. Following which, the second week, will begin with 15 minutes (including two minutes warm-up and two minutes cool-down of passive cycling) of cycling, and duration should be increased each session by 3.3 minutes (i.e. 10 minutes will be added each week) until a total duration of 45 minutes is achieved in the fifth week. Patients should not voluntarily contribute to the pedaling instead they should concentrate on the exercise. Throughout passive cycling, the legs of patient are required to be moved only by the ergometer's motor that assures a steady speed of 20 revolutions per minute (rpm) during the training session. The exercise intensity for each session should be set and monitored as a percentage of the individual heart rate reserve. ${ }^{20}$

As a concurrent treatment to the cycling, it is recommended that patients utilize a current-controlled 8-channel stimulator and surface electrodes in a bipolar configuration on both legs' quadriceps, gluteus maximum, hamstrings, and tibialis anterior. Rectangular biphasic pulses with pulse width of 100-400 $\mu$ s (should be based on personal acceptable tolerance), stimulation frequency of $20-40 \mathrm{~Hz}$ (should be based on personal acceptable tolerance), and the amplitude of 20 to $100 \mathrm{~mA}$ (should based on personal acceptable tolerance) should be utilized. In addition, numerous parameters concerning power and temporal sequence of the impulses should be adjusted individually for each channel. In addition to personal tolerance, the intensity of stimulus for each muscle should be set at a tolerated value that creates a visibly good muscle reduction. ${ }^{21}$ The timing of the stimulation should be synchronized to the cycling 
movement based on physiological stereotype activation patterns. ${ }^{22}$ To encourage a comparable mental set, patients should undergo an initiation sessions in an attempt to familiarize to sensations and to what is considered a visibly good muscle. ${ }^{23}$

The most important differences between this suggested hypothesis with previous studies is related to progressive pattern of cycling, as most of the previous studies, used a fixed duration of cycling and as such, made the therapeutic process longer. Based on this hypothesis, concurrent cycling training and FES would result in superior improvements in cycling performance, aerobic capacity, and functional performance in post-stroke patients as a result of an increased activation of cortical regions.
In this regard, this method may prove particularly useful for those patients suffering a traumatic brain injury or first-time stroke that results in hemiparesis with an acute event interval ( $<6$ months). However, these patients must display adequate cognition and be able to carry out active standard cycling treatment (i.e. able to sit up to 30 minutes, low spasticity in the lower limb muscles (modified Ashworth score $<2$ ) and display joint mobility ranges which would not prevent pedaling).

All authors declare no potential conflict of interest related to this article.

AUTHORS' CONTRIBUTIONS: Each author made significant individual contributions to this manuscript. NNA $(0000-0003-2742-2273)^{*}$ and AS $(0000-0002-1877-4747)^{*}$ and RK (0000-0002-1877-4747) were responsible for writing of the draft and interpretation, and they had substantial contribution in the design. BSS (0000-0002-2285-8361)* and IS (0000-0001-8400-8234)* helped with final writing of the manuscript and revision of its intellectual content. MK (0000-0001-9335-2889)* designed the study and supervised the procedures, and supervised the writing of the final manuscript. All authors read and approved the final manuscript. *ORCID (Open Researcher and Contributor ID).

\section{REFERENCES}

1. Sarti C, Rastenyte D, Cepaitis Z, Tuomilehto J. International trends in mortality from stroke, 1968 to 1994. Stroke. 2000;31(7):1588-601.

2. Cordun M, Marinescu GA. Functional rehabilitation strategies for the improvement of balance in patients with hemiplegia after an ischemic stroke. Procedia-Social and Behavioral Sciences. 2014;117:575-80.

3. Yoshimoto Y, Oyama Y, Tanaka M, Sakamoto A. One-leg standing time of the affected side moderately predicts for postdischarge falls in community stroke patients. J Stroke Cerebrovasc Dis. 2016;25(8):1907-13.

4. Kim EK, Lee DK, Kim YM. Effects of aquatic PNF lower extremity patterns on balance and ADL of stroke patients. J Phys Ther Sci. 2015;27(1):213-5.

5. Raghavan P, Geller D, Guerrero N, Aluru V, Eimicke J, Teresi JA, et al. Music Upper Limb Therapy—Integrated: An Enriched Collaborative Approach for Stroke Rehabilitation. Front hum neurosci. 2016;10:498.

6. Winstein CJ, Stein J, Arena R, Bates B, Cherney L, Cramer SC, et al. Guidelines for adult stroke rehabilitation and recovery. Stroke. 2016;49(4):e98-169.

7. Vanroy C, Feys H, Swinnen A, Vanlandewijck Y, Trujien S, Vissers D, et al. Effectiveness of Active Cycling in Subacute Stroke Rehabilitation: A Randomized Controlled Trial. Arch Phys Med Rehabil. 2017;98(8):1576-85.

8. Gordon NF, Gulanick M, Costa F, Fletcher G, Franklin B, Roth EJ, et al. Physical activity and exercise recommendations for stroke survivors. Circulation. 2004; 109:2031-41.

9. Tohoku J. Therapy for hemiparesis alleviates disability and enhances neuroplasticity. Exp Med. 2011;225(1):71-6.

10. Faisal CKM, Priyabandani NOP, Ajith S. Efficacy of functional neuromuscular electrical stimulation (FNMES) in the improvement of hand functions in acute stroke survivals. Nitte University Journal of Health Science. 2012;2(4):16-21.

11. Yang $H C$, Lee $C L$, Lin $R$, Hsu MJ, Chen CH, Lin JH, et al. Effect of biofeedback cycling training on functional recovery and walking ability of lower extremity in patients with stroke. Kaohsiung J Med Sci. 2014;30(1):35-42

12. Bauer P, Krewer C, Golaszewski S, Koenig E, Müller F. Functional Electrical Stimulation-Assisted Active
Cycling - Therapeutic Effects in Patients With Hemiparesis From 7 Days to 6 Months After Stroke: A Randomized Controlled Pilot Study. Arch Phys Med Rehabil. 2015;96(2):188-96.

13. Jung T, Ozaki Y, Lai B, Vrongistinos K. Comparison of Energy Expenditure Between Aquatic and Overground Treadmill Walking in People Post-Stroke. Physiother Res Int. 2014;19(1):55-64.

14. Likhi M, Jidesh VV, Kanagaraj R, George JK. Does trunk, arm, or leg control correlate best with overall function in stroke subjects? Top Stroke Rehabil. 2013;20(1):62-7.

15. Mansfield A, Wong JS, Bryce J, Brunton K, Innes EL, Knorr S, et al. Use of accelerometer-based feedback of walking activity for appraising progress with walking-related goals in inpatient stroke rehabilitation: a randomized controlled trial. Neurohabil Neural Repair. 2015;29(9):847-57.

16. Cullen KE. Sensory signals during active versus passive movement. Curr Opin Neurobiol. 2004;14(6):698-706

17. Dechaumont-Palacin S, Marque P, De Boissezon X, Castel-Lacanal E, Carel C, Berry I, et al. Neural correlates of proprioceptive integration in the contralesional hemisphere of very impaired patients shortly after a subcortical stroke: an FMRI study. Neurorehabil Neural Repair. 2008;22(2):154-65.

18. Eraifej J, Clark W, France B, Desando S, Moore D. Effectiveness of upper limb functional electrical stimulation after stroke for the improvement of activities of daily living and motor function: a systematic review and meta-analysis. Syst Rev. 2017;28(1):40.

19. Howlett OA, Lannin NA, Ada L, McKinstry C. Functional electrical stimulation improves activity after stroke: a systematic review with meta-analysis. Arch Phys Med Rehabil. 2015;96(5):934-43.

20. Janssen TW, Beltman JM, Elich P, Koppe PA, Konjinenbelt H, de Haan A, et al. Effects of Electric Stimulation- Assisted Cycling Training in People With Chronic Stroke. Arch Phys Med Rehabil. 2008;89(3):463-9.

21. Ambrosini E, Ferrante S, Pedrocchi A, Ferrigno G, Molteni F. Cycling induced by electrical stimulation improves motor recovery in postacute hemiparetic patients. Stroke. 2011;42(4):1068-73.

22. Trevisi E, Gualdi S, De Conti C, Salguetti A, Martinuzzi A, Pedrocchi A, et al. Cycling induced by functional electrical stimulation in children affected by cerebral palsy: case report. Eur J Phys Rehabil Med. 2012;48(1):135-45.

23. Kargarfard M, Shariat A, Ingle L, Cleland JA, Kargarfard M. Randomized Controlled Trial to Examine the Impact of Aquatic Exercise Training on Functional Capacity, Balance, and Perceptions of Fatigue in Female Patients With Multiple Sclerosis. Arch Phys Med Rehabil. 2018; 99(2), 234-41. 